American Journal of Applied Sciences 6 (7): 1327-1330, 2009

ISSN 1546-9239

(C) 2009 Science Publications

\title{
Reduction of Isolation Period of Coal Humic Acids
}

\author{
${ }^{1}$ Claudia Hui Hui Chen, ${ }^{1}$ Osumanu Haruna Ahmed, \\ ${ }^{1}$ Nik Muhamad Ab. Majid and ${ }^{2}$ Mohamadu Boyie Jalloh \\ ${ }^{1}$ Department of Crop Science, Faculty of Agriculture and Food Science, \\ University Putra Malaysia Bintulu Campus, Sarawak, 97008 Bintulu, Sarawak, Malaysia \\ ${ }^{2}$ School of Sustainable Agriculture, University Malaysia Sabah, \\ Locked Bag 2073, 88999 Kota Kinabalu, Sabah, Malaysia
}

\begin{abstract}
Problem statement: The isolation of Humic Acids (HA) from coal is laborious, costly and time consuming. The extraction and fractionation periods of HA vary from $4 \mathrm{~h}$ to 7 days. Fractionation period ranges from 12-24 h. However, most studies use $24 \mathrm{~h}$ as extraction period and also $24 \mathrm{~h}$ as fractionation period. This study was conducted to investigate whether the isolation period for HA of coals could be reduced. Approach: Different extraction periods using $0.1 \mathrm{M} \mathrm{NaOH}(4,8,12,16,20$ and $24 \mathrm{~h}$ ) were tested. Samples were centrifuged $(16,211 \mathrm{G}$ for $15 \mathrm{~min})$ at the end of each extraction period. The dark-colored supernatant liquor containing $\mathrm{HA}$ was decanted and the $\mathrm{pH}$ of solution was adjusted to 1.0 using $6 \mathrm{M} \mathrm{HCl}$. After acidification, the fractionation periods evaluated were 4, 8, 12, 16,20 and $24 \mathrm{~h}$. The samples were transferred to a polyethylene bottle and centrifuged (16, $211 \mathrm{G}$ for $10 \mathrm{~min}$ ) after each fractionation period. The HA purification was done by suspending them in $50 \mathrm{~mL}$ distilled water and centrifuged $(16,211 \mathrm{G}$ for $10 \mathrm{~min})$. HA samples were dried in an oven at $40^{\circ} \mathrm{C}$ to a constant weight. Standard procedures were used to characterized the HA (total carbon, $\mathrm{E}_{4} / \mathrm{E}_{6}$, phenolic $\mathrm{OH}$, carboxylic $\mathrm{COOH}$ and total acidity). Results: There was significant effect of both extraction and fractionation periods on the isolation of HA from coal. The optimum period for Na ions to saturate the exchange complex of HA during the extraction process was $8 \mathrm{~h}$ while the optimum period for the exchanges sites of the HA to be saturated with $\mathrm{H}$ ions during the fractionation process was $20 \mathrm{~h}$. The distilled water used in this study was able to purify HA within $1 \mathrm{~h}$ because it served as Bronsted-Lowry acid. Additionally, carbon, $\mathrm{E}_{4} / \mathrm{E}_{6}$, phenolic $\mathrm{OH}$, carboxylic $\mathrm{COOH}$ and total acidity of the HA were typical of those reported in the literature, suggesting that that the isolation process of the HA was successful. Conclusion: The isolation period of HA from coal can be reduced to $29 \mathrm{~h}(8 \mathrm{~h}$ extraction, $20 \mathrm{~h}$ fractionation period and $1 \mathrm{~h}$ purification period) instead of the existing range of 2-7 days.
\end{abstract}

Key words: Coal, humic acids isolation, extraction period, fractionation period

\section{INTRODUCTION}

Malaysia's coal resources are estimated at 1,050 million tones of various qualities, ranging from lignite to anthracite; bituminous to sub-bituminous coal. About 69\% is found in Sarawak, 29\% in Sabah and 2\% in Peninsular Malaysia from the total amount of coals. Coal rich in humic matter is formed in time from peat. The isolation of Humic Acids (HA) from coal is laborious, costly and time consuming. The extraction and fractionation periods of HA vary from $4 \mathrm{~h}$ to 7 days $^{[1-3]}$. Fractionation period ranges from $12-24 \mathrm{~h}^{[2,5]}$. However, most studies use $24 \mathrm{~h}$ as extraction period ${ }^{[5-8]}$ and also $24 \mathrm{~h}$ as fractionation period ${ }^{[5,7,9]}$.
Recent studies have shown that the extraction period in isolating HA from Hemists peat soil can be reduced to $4 h^{[10]}$. Fractionation period in isolating HA from peat soil has also been reduced to $2 \mathrm{~h}^{[10]}$. In the study on purification of HA, the period of purification of HA had been reduced to $1 \mathrm{~h}^{[10]}$. Another study has also shown that HA isolated from composted pineapple leaves could be purified in between 1-2 $\mathrm{h}^{[9]}$. Information of this kind for the isolation of $\mathrm{HA}$ is lacking for coal. To date, not much study has been made for HA isolation period for coal. The objective of this study was to reduce the isolation period of coal HA.

Corresponding Author: Osumanu Haruna Ahmed, Department of Crop Science, Faculty of Agriculture and Food Science, University Putra Malaysia Bintulu Campus, Sarawak, 97008 Bintulu, Sarawak, Malaysia Tel: +6086855406 Fax: +608685415 


\section{MATERIALS AND METHODS}

The source of the coal used in this study was obtained from Mukah, Sarawak, Malaysia. The HA isolation was conducted using the procedures outlined in related research ${ }^{[3,7,8,10]}$.

Five grams (dry weight basis) of coal sample at natural moisture content were placed into polyethylene centrifuge bottles and $50 \mathrm{~mL} 0.1 \mathrm{M} \mathrm{NaOH}$ solution was added and bottles were stoppered tightly with rubber stoppers. The samples were equilibrated at room temperatures $\left(25^{\circ} \mathrm{C}\right)$ on a reciprocal mechanical shaker. The extraction period used in this study were 4 (EP4), 8 (EP8), 12 (EP12), 16 (EP16), 20 (EP20) and 24 (EP24) h. At the end of the each extraction, the samples were centrifuged at $16,211 \mathrm{G}$ for $15 \mathrm{~min}$. The dark colored supernatant liquors were decanted, the $\mathrm{pH}$ of the solutions were then adjusted to 1.0 with $6.0 \mathrm{M} \mathrm{HCl}$ and the HA were allowed to stand at room temperature.

The fractionation periods used immediately after acidification were 4 (FP4), 8 (FP8), 12 (FP12), 16 (FP16), 20 (FP20) and 24 (FP24) h. At the end of each fractionation, the excess supernatant liquors (fulvic acid) were siphoned off from the acidified extracts. The remainders of the suspensions containing the HA were transferred to polyethylene bottles and centrifuged at $16,211 \mathrm{G}$ for $10 \mathrm{~min}$. The HA samples were purified by washing them in $50 \mathrm{~mL}$ of distilled water through centrifugation at $16,211 \mathrm{G}$ for $10 \mathrm{~min}$ to reduce mineral matter. This procedure was repeated 3 times after which the washed HA samples were oven dried at $40^{\circ} \mathrm{C}$ to a constant weight, weighed and yields expressed as percentage by weight of HA in the coal used.

The purified HA were characterized by the Loss on Ignition method ${ }^{[11]}$. In this method, HA samples were placed into oven at $60^{\circ} \mathrm{C}$ for $6 \mathrm{~h}$ after which they placed in dessicator for cooling. A $5 \mathrm{~g}$ of the oven dried HA samples were placed into crucibles. The crucibles were weighed together with the samples and placed in Muffle Furnace and temperature raised to $400^{\circ} \mathrm{C}$ for $4 \mathrm{~h}$. After $4 \mathrm{~h}$, crucibles were removed from Muffle Furnace and cooled in dessicator and afterwards the samples were weighed.

$\mathrm{E}_{4} / \mathrm{E}_{6}$ ratio of $\mathrm{HA}$ was determined by method described by ${ }^{[3]}$. Humic acids samples of $2 \mathrm{mg}$ were dissolved in $10 \mathrm{~mL}$ of $0.05 \mathrm{M} \mathrm{NaHCO}_{3}$, which gave an optimum $\mathrm{pH}$ for absorbance measurements. Solution was recorded in $1 \mathrm{~cm}$ cell on a Lambda $25 \mathrm{UV} / \mathrm{VIS}$ Spectrometer at $465 \mathrm{~nm}$ and $665 \mathrm{~nm}$ wavelength and $\mathrm{E}_{4} / \mathrm{E}_{6}$ ratio was obtained.

Total acidity of the purified HA was determined by the method described by ${ }^{[7]}$. Total acidity was the summation of carboxylic acidity and phenolic acidity.
In this method, $0.02 \mathrm{~g}$ of HA samples were dissolved in $4 \mathrm{~mL}$ of $0.08 \mathrm{M} \mathrm{NaOH}$ and they were shaken at $120 \mathrm{rpm}$ for $30 \mathrm{~min}$. Afterwards the initial $\mathrm{pH}$ of the solution was taken at the value of 10 . Titration was done with $0.1 \mathrm{M}$ of $\mathrm{HCl}$ until the $\mathrm{pH}$ reached 2.5. The whole titration process was completed in $15 \mathrm{~min}$.

The complete isolation process (extraction, fractionation and purification) for this study was repeated 3 times; hence the values used in this study were the means of these replications. The relationship between extraction period, fractionation period and the yield of HA as well as the relationship between both variables (extraction and fractionation period) on the yields of HA were evaluated using the Statistical Analysis System (SAS) version 9.1. Analysis of variance was used to test treatment effects while means of treatments were compared using Duncan's New Multiple Range Test (DNMRT).

\section{RESULTS}

The effect of extraction period on the yield of HA obtained from coal is shown in Fig. 1. The HA yield of EP8 and EP16 were statistically similar but were significantly different from EP4 and EP12, EP20 and EP24. EP12, EP20 and EP24 were also statistically similar. The means of EP8 and EP16 were $8.13 \%$ and $8.27 \%$. These values were higher compared to the yields of EP4, EP12, EP20 and EP24 which were 2.31, $4.93,5.23$ and $5.09 \%$ respectively. Since EP 8 was statistically higher than other extraction periods except for EP16, extraction period of $8 \mathrm{~h}$ can be considered as the optimum period for extracting HA from the coal investigated.

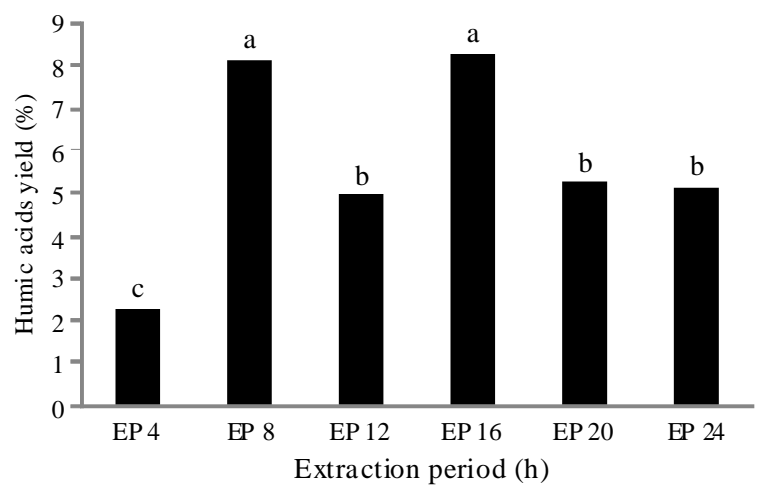

Fig. 1: Effect of Extraction Period (EP) on HA yield Note: Bars with different alphabets indicate significant difference between different extraction periods and yield of HA using Duncan's new multiple range test at $p=0.05$ 
Am. J. Applied Sci., 6 (7): 1327-1330, 2009

Table 1: Interaction between Fractionation Periods (FP) under different Extraction Periods (EP)

\begin{tabular}{lllllll}
\hline & FP 4 & FP 8 & FP 12 & FP 16 & FP 20 & FP 24 \\
\hline EP 4 & $2.95^{\mathrm{ab}}$ & $3.72^{\mathrm{a}}$ & $1.27^{\mathrm{d}}$ & $1.42^{\mathrm{dc}}$ & $1.91^{\mathrm{dc}}$ & $2.29^{\mathrm{bc}}$ \\
EP 8 & $6.38^{\mathrm{bc}}$ & $3.25^{\mathrm{c}}$ & $4.01^{\mathrm{cb}}$ & $3.09^{\mathrm{c}}$ & $19.21^{\mathrm{a}}$ & $8.93^{\mathrm{b}}$ \\
EP12 & $5.93^{\mathrm{a}}$ & $6.43^{\mathrm{a}}$ & $5.05^{\mathrm{a}}$ & $4.68^{\mathrm{a}}$ & $3.10^{\mathrm{a}}$ & $4.41^{\mathrm{a}}$ \\
EP16 & $6.73^{\mathrm{bc}}$ & $6.31^{\mathrm{bc}}$ & $6.09^{\mathrm{c}}$ & $10.92^{\mathrm{a}}$ & $8.97^{\mathrm{ab}}$ & $11.51^{\mathrm{a}}$ \\
EP20 & $6.51^{\mathrm{a}}$ & $5.34^{\mathrm{a}}$ & $4.61^{\mathrm{a}}$ & $3.91^{\mathrm{a}}$ & $5.13^{\mathrm{a}}$ & $5.91^{\mathrm{a}}$ \\
EP24 & $5.23 \mathrm{~b}^{\mathrm{a}}$ & $6.33^{\mathrm{a}}$ & $5.97^{\mathrm{a}}$ & $3.95^{\mathrm{ab}}$ & $5.77^{\mathrm{ab}}$ & $3.24^{\mathrm{b}}$ \\
\hline
\end{tabular}

Note: Means within row with different letter indicate significant difference between Fractionation Period (FP) using Duncan's New Multiple Range Test at $\mathrm{p}=0.05$

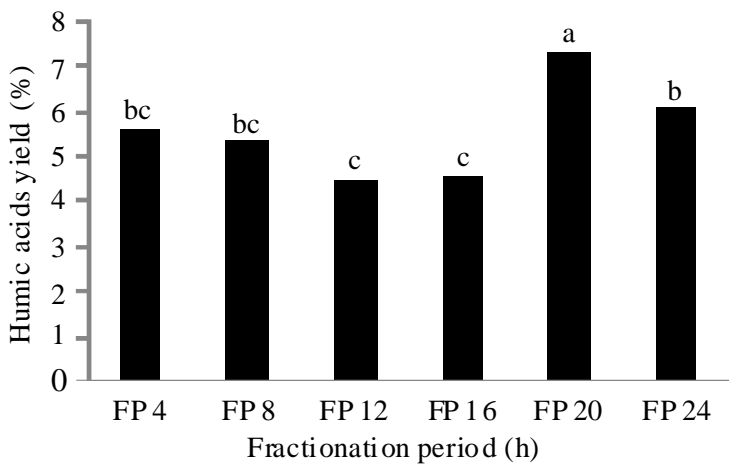

Fig. 2: Effect of Fractionation Period (FP) on HA yield. Note: Bars with different alphabets indicate significant difference between different fractionation periods and yield of HA using Duncan's new multiple range test at $\mathrm{p}=0.05$

The effect of different fractionation period on the yield of HA is shown in Fig. 2. There was significant effect of fractionation period on the yield of HA. The means of FP 4, FP 8 and FP 24 were statistically higher than FP 12 and FP 16 but lower than FP 20. FP 20 showed the highest mean value which was $7.35 \%$. Since FP 20 was statistically higher than the other fractionation periods, it suggests that it takes $20 \mathrm{~h}$ for the exchange site of HA in coal to be saturated with $\mathrm{H}$ ions after acidification.

There was significant interaction between fractionation period and extraction period (Table 1). The yields of HA of EP 12 and EP 20 under FP 4, FP 8, FP12, FP16, FP 20 and FP 24 were not statistically significant while the contrary was true for EP4, EP8, EP16 and EP24 for these fractionation periods.

The phenolic-OH, carboxylic-COOH and total acidity ranges of the HA extracted from the investigated coal were found to be within the ranges of standard values (Table 2). The phenolic-OH ranged from 150$450 \mathrm{cmol} \mathrm{kg}^{-1}$ and the carboxylic- $\mathrm{COOH}$ ranged from $400-500 \mathrm{cmol} \mathrm{kg}^{-1}$. The summation of phenolic-OH and carboxylic- $\mathrm{COOH}$ was the total acidity and it ranged from $600-900 \mathrm{cmol} \mathrm{kg}^{-1}$. The ratios of $\mathrm{E}_{4} / \mathrm{E}_{6}$ of the HA were between 3.19 and 2.30 (Table 2).
Table 2: Comparison of the ranges of carboxylic- $\mathrm{COOH}$, phenolic$\mathrm{OH}$, total acidity and $\mathrm{E}_{4} / \mathrm{E}_{6}$ of the investigated coal with standard values

\begin{tabular}{|c|c|c|}
\hline Variable & HA, Present study & Reference \\
\hline Phenolic-OH $\left(\mathrm{cmol} \mathrm{kg}^{-1}\right)$ & $150-450$ & $150-440^{\mathrm{a}}$ \\
\hline Carboxylic-COOH $\left(\mathrm{cmol} \mathrm{kg}^{-1}\right)$ & $400-500$ & $240-540^{\mathrm{a}}$ \\
\hline Total acidity $\left(\mathrm{cmol} \mathrm{kg}^{-1}\right)$ & $600-900$ & $570-890^{\mathrm{b}}$ \\
\hline $\mathrm{E}_{4} / \mathrm{E}_{6}$ & $2.30-3.19$ & $<$ than $5.0^{\mathrm{c}}$ \\
\hline
\end{tabular}

Table 3: Comparison of total carbon (\%) and the total ash content (\%) with related references

\begin{tabular}{lll}
\hline Variable & HA, present study & References \\
\hline Total carbon $(\%)$ & $53.81 \%$ & $48.90-58.50^{\mathrm{a}}$ \\
Total ash content $(\%)$ & $0.5-29.5$ & $<1.0 \%{ }^{\mathrm{b}}$ \\
\hline${ }^{\mathrm{a}}: \operatorname{Tan}^{[4]} ;{ }^{\mathrm{b}}:$ Schnitzer $^{[5]}$ & &
\end{tabular}

The mean of the total carbon found in the HA samples isolated from coal was $53.81 \%$ while total ash content of the HA samples ranged from 0.5-29.5\%. The total carbon of was typical of any HA but the ash content range was high (Table 3 ).

\section{DISCUSSION}

Generally, the yield of HA decreased after extraction period of $8 \mathrm{~h}$ (EP 8) except for EP 16 which happened to be not statistically different from EP 8 . This was due to the exchanged process of $\mathrm{Na}$ ions at the exchanged sites (oxygen containing functional groups) of coal which progressed with the extraction period until $16 \mathrm{~h}$, a period where most of these sites may have been saturated with $\mathrm{Na}$ ions making the coals soluble hence the maximum yield at this extraction period. The difficulty of extracting the humic substances in the initial shorter period (e.g., $4 \mathrm{~h}$ ) was due to the difficulty in wetting the coals which are usually formed from irreversible drying of peat soils ${ }^{[3]}$. Additionally, the lower yields with longer extraction period are because prolonged extraction period causes significant chemical changes in $\mathrm{HA}^{[5]}$. Since the HA yields of EP 8 and EP 16 were not statistically different, extraction period of $8 \mathrm{~h}$ corresponding to HA yield of $8.13 \%$ could be considered optimum. This is because beyond $8 \mathrm{~h}$, the yield of HA may not be time wise economically justifiable

The yield of HA was significantly affected by the fractionation period immediately after acidification. Since FP 20 was significantly higher than the other fractionation period, it was assumed that the minimum fractionation time in this study was $20 \mathrm{~h}$ for the exchange sites of coals $\mathrm{HA}$ to be saturated with $\mathrm{H}$ ions after acidification. Moreover, the fact that there was significant interaction between extraction period and fractionation period suggests that the performances of 
the different fractionation periods with any of the extraction periods are not the same. As a result, it is reasonable to assume that $20 \mathrm{~h}$ of equilibration after acidification is sufficient to displace the sodium ions with hydrogen ions at the HA exchange sites. This also implies that the effectiveness of fractionation was dependent on the duration of extraction.

The carboxylic-COOH was found to be within the ranges reported by other authors, but the phenolic-OH was slightly higher than the ranges reported by other authors causing the total acidity of HA samples to be slightly higher. This indicate that the washing of HA samples were less effective. Additionally, the $\mathrm{E}_{4} / \mathrm{E}_{6}$ values of the HA which indicate the humification level were lower than the ranges reported by other authors. The low values of $\mathrm{E}_{4} / \mathrm{E}_{6}$ ratio are due to the higher molecular weight and condensation ${ }^{[11]}$ concluded that the $E_{4} / E_{6}$ ratios of $H A$ were governed primarily by the particles sizes and weights (due in part to scattering of light). Ratio for HA is usually less than $5.0^{[3]}$.

The mean of the total carbon content in this study was found to be within the range reported in the literature while the ash content ranges were higher than the references. The reason why ash content was high in the HA samples is because of the ineffectiveness in washing HA samples during purification. High ash content is usually accompanied by the significant high in inorganic impurities of HA samples.

\section{CONCLUSION}

The optimum yield of HA from the investigated coal could be obtained at the extraction period of $8 \mathrm{~h}$. There was significant interaction between extraction period and fractionation period. Fractionation period immediately after acidification significantly affected the yield of HA from investigated coals. Twenty hours of fractionation period is required to precipitate HA of the coals. The HA can be purified within $1 \mathrm{~h}$ using distilled water. The significance of this study is that HA of coals can be isolated within 29 h (i.e., 8 h extraction period, $20 \mathrm{~h}$ fractionation period and $1 \mathrm{~h}$ purification period) instead of the existing range of 2-7 days, hence it helps in facilitating the idea of producing humates fertilizer from coals HA.

\section{ACKNOWLEDGEMENT}

The researchers acknowledge the financial support of this research by the Ministry of Higher Education Malaysia.

\section{REFERENCES}

1. Goh, K.M. and M.R. Reid, 1975. Molecular weight distribution of soil organic matter as affected by acid pretreated and fractionation into humic acid and fulvic acids. J. Soil Sci., 26: 207-217. DOI: 10.1111/j.1365-2389.1975.tb01944.x

2. Kakezawa, M. T. Nishida and Y. Takahara, 1992. Structural characteristics of humic acids extracted from woody composts by two-step composting processs. Soil Sci. Plant Nutr., 38: 85-92. http://ci.nii.ac.jp/naid/110001720098/

3. Stevenson, F.J., 1994. Humus Chemistry: Genesis, Composition and Reactions. 2nd Edn., John Wiley and Son, New York, ISBN: 0471594741, pp: 496.

4. Tan, K.H., 1996. Soil Sampling, Preparation and Analysis. Marcel Dekker, Inc., New York, ISBN: 0824796756, pp: 408.

5. Schnitzer, M. and C.M. Preston, 1986. Analysis of humic acids by solution and solid state carbon-13 nuclear magnetic resonance. Soil Sci. Soc. Am. J., 50: 326-331.

http://soil.scijournals.org/cgi/content/abstract/50/2/326

6. De Nobili, M., G.J. Bragato, M. Alcaniz, A. Puigbo and L. Comelllas, 1990. Characterization of electrophoretic fractions of humic substances with different electrofocusing behavior. Soil Sci., 150: 763-770. http://www.fao.org/agris/search/display.do?f=./199 1/v1705/US9108850.xml;US9108850

7. Inbar, Y., Y. Chen and Y. Hadar, 1990. Humic substances formed during the composting of organic matter. Soil Sci. Am. J., 54: 1316-1323. http://soil.scijournals.org/cgi/content/abstract/54/5/1316

8. Amalfitano, C. R.A. Quezada, M.A. Wilson and J.V. Hanna, 1995. Chemical composition of humic acids: A comparison with precursor 'light fraction' litter from different vegetations using spectroscopic techniques. Soil Sci., 150: 391-401. http://cat.inist.fr/?aModele=afficheN\&cpsidt=3582871

9. Ahmed, O.H., M.H.A. Husni, A.R. Anuar, M.M. Hanafi and E.D.S. Angela, 2004. A modified way of producing humic acid from composted pineapple leaves. J. Sust. Agric., 25: 129-139. http://direct.bl.uk/bld/PlaceOrder.do?UIN=161720 160\&ETOC $=$ RN\&from $=$ searchengine

10. Susilawati, K., O.H. Ahmed, A.M. Nik Muhamad and M.Y. Khanif, 2007. Effects of extraction and fractionation period on the yield of a tropical peat soil (Hemists) humic acids. Am. J. Agri. Biol. Sci., 2: 202-205. http://www.scipub.org/fulltext/AJAB/AJAB23202-205.pdf

11. Barak, P. and Y. Chen., 1992. Equivalent radii of humic macromolecules from acid-base titration. Soil. Sci., 152: 184-195. http://direct.bl.uk/bld/PlaceOrder.do?UIN=000806 $626 \&$ ETOC $=\mathrm{EN} \&$ from $=$ searchengine 